\title{
Chapter 11 \\ Duality of Humans: The Wish to Learn and Not to Learn
}

\author{
Andria D. Timmer and Máté Erôs
}

\begin{abstract}
The segregated nature of education for the Hungarian Roma has been well-documented. Solutions to overcoming this segregation are often focusing on adding education interventions tailored to Roma youth. We argue that although education can be empowering, it can also be used as a tool to maintain the status quo. Education is dualistic and paradoxical in that it can both empower and enslave. In this chapter we use a philosophical lens to examine how the dualistic nature of education and humans can cause impediments to equal access to quality education for the Hungarian Roma. We identify some of the real obstacles to providing education to Hungarian Roma and disadvantaged youth, outline the philosophical underpinnings of these obstacles, and propose potential solutions. We use a school that has had success in providing educational tools for Roma and disadvantaged youth, MÁV School in Budapest, as a model to explain both the paradoxes and the solutions to overcome these paradoxes. Our goal is to provide insight into the educational situation for the Hungarian Roma and to make space for the reader to implement different attitudes and strategies to succeed in creating a sustainable model of education for Roma and other marginalized youth.
\end{abstract}

Keywords Roma $\cdot$ Education $\cdot$ Dualism $\cdot$ Segregated schooling $\cdot$ Hungary

The segregation of Roma youth in primary and secondary schooling throughout Europe has been well-documented by academics (Danova 2004; O’Nions 2010; Timmer 2017), governing bodies (European Commission 2004; EUMAP 2007), and non-governmental organizations (ERRC 2004; Rorke 2016). The reason for and the nature of segregated education is complex and multifaceted but often incompletely and inadequately explained as a factor of segregated and isolation living created by

\footnotetext{
A. D. Timmer

Christopher Newport University, Newport News, VA, USA

e-mail: andria.timmer@cnu.edu

M. Erôs ( $\square)$

John Wesley College Budapest, Budapest, Hungary
} 
and exacerbated by discrimination and distrust between Roma and non-Roma. For the past few decades, there has been a great influx of educational programs and interventions designed to extend schooling resources to Roma and other similarly disadvantaged youth based on the premise that once armed with an education, they will be more employable and better able to integrate into mainstream society. In Hungary, these interventions include funding and support for integrated classrooms, afterschool programs to help Roma students who have been left out of the education system to catch up with their peers, and segregated schools which teach Roma (and similarly disadvantaged) youth separately from their peers but with a focus on quality and student-focused pedagogy.

The premise behind all of these interventions is that education is empowering. That is, through education marginalized people will be armed with the tools to fight against discrimination and throw off the shackles of their oppression. We do not deny the power of education to do just this. However, we must also contend with the reality that the schooling system largely maintains social inequalities and hierarchies and does not break them down. Schools, more often than not, reify class differences by teaching students their prescribed social roles and their duties as citizens (Anyon 1980; Willis 1977). They "impose the legitimate forms of discourse and the idea that discourse should be recognized if and only if it conforms to the legitimate norms" (Bourdieu 1977; see also Foucault 1977). In practice, what this means for the Roma is that school serves as a tool to prepare them for the low skill, blue collar jobs they are likely to procure if they are able to find employment. As a result, Roma youth do not feel valued in the classroom personally or culturally because they are both explicitly and implicitly taught that the only choice they have in order to be successful in life is to conform to the "legitimate discourse" and suppress their unique identities.

Given the constraints of the education system, those who wish to intervene by providing accessible quality education to Roma are faced with two challenges. The first is how to work within the system to subvert the system. That is, how can educators make education truly empowering? The second challenge relates to the specific issues involved in working with Roma. As a segregated and discriminated against population, Roma youth do not speak the "language of school" (Derdák and Varga 1996) and have not been socialized into being "proper" students. Moreover, and more importantly, education as the reproduction of the status quo holds little value for the Roma community until it results is discernable positive results. In this chapter, we examine some of the real obstacles to providing education to Hungarian Roma and disadvantaged youth, outline the philosophical underpinnings of these obstacles, and propose potential strategies for solutions that have been tested at one school located in a segregated Roma neighborhood in Budapest, Hungary. We propose that in order to meet the needs of Roma and disadvantaged youth, educators and activists must be willing to abandon traditional means of instruction and strive to find new and innovative ways to engage students who heretofore have been left out of the educational system. Our goal is to provide insight into the educational situation for the Hungarian Roma and to make suggestions for different attitudes 
and strategies necessary to succeed in creating a sustainable model of education for Roma and other marginalized youth.

\section{Who Are We?}

The authors of this chapter have several years of experience as educators and activists in the field of Roma education. The first author is an anthropologist who has conducted ethnographic research on and in education interventions for the Roma in Hungary since 2004. Timmer conducted 18 months of field research at Roma educational institutions and also worked as an English teacher at a school with a largely Roma student body. The second author is a philosopher who worked as the headmaster of MÁV school, a segregated school in Budapest. The challenges and examples identified in this chapter largely emerge from Máté Erôs's direct experience in building a school that will do what it sets out to do-provide quality education for Roma (and similarly disadvantaged) youth. Using a philosophical understanding of how humans learn and come to education, Erôs and his team developed an institution that provides a sense of achievement for the students who attend through alternative "guerilla" pedagogies and methods (Mizsur 2018). In writing this chapter, the authors draw upon their experiences as field researchers and educators. We present this analysis as a critical insight into some of the challenges those working with Roma face on a daily basis and some potential ideas on ways in which educators can work to overcome these challenges. Philosophical theory enables us to articulate why education provides such a challenge to Roma and educators alike; ethnography enables us to elucidate strategies that have been effectively implemented.

The challenges we discuss in this chapter emerge from experience in several educational institutions in Hungary that provide schooling for Roma youth as well as an extensive review of the scholarly literature and governmental and non-governmental documentation. The strategies we propose emerge from our experiences providing instruction in these institutions as well as through observation and conversation with educators of disadvantaged youth. During his time as headmaster at MÁV school, Erôs experimented with different techniques to engage and excite students who would otherwise be disengaged from the learning process. Since leaving MÁV school, Erôs has worked to implement the skills he developed there in a variety of different institutions working to address educational disparities and social, ethnic, and economic minorities. Together, Erôs and Timmer have visited several schools and spoken with many educators who strive to create the best possible resources for disadvantaged students, the majority of whom are Roma. Through our experiences, we conclude that in order to best serve the needs of the Roma populations, educators must (1) employ a positive method of education that focuses on reward rather than punishment, (2) accept their students where they are rather than attempt to mold them into an uncomfortable and unfamiliar model of the 
"ideal student", and (3) be willing to apply methods of teaching that do not conform to the state curricular ideologies.

Much of the inspiration for this chapter comes from Erôs's work and Timmer's observations at MÁV school. As headmaster, Erôs had greater freedom here to be experimental because the school is a church funded institution. According to the Hungarian public education law, churches have the ability to use state and private funds to establish and run schools. However, with state funding comes the obligation to work in strict accordance with the state-defined curriculum and use statesponsored curricular materials. This is exceedingly problematic in that it hinders one's ability to offer the alternative pedagogies that researchers and practitioners have found essential for the education of disadvantaged populations, for reasons we will explain below. What makes MÁV school most intriguing, is that the church is not approved by the state. In 2010, Viktor Orbán was elected prime minister of Hungary and his election ushered in an era of right-wing populism. Shortly after his election, Orbán created new church legislation which deprived legal status to several established churches, including the church which oversees MÁV school, the Hungarian Evangelical Fellowship (MET). MET has not been an officially recognized church since 2011 and as a result has been starved of many necessary state subsidies (Kingsley 2019). Obviously, this lack of funding has led to financial difficulties within the church and the schools, homeless shelters, and nursing homes the church oversees. However, the lack of government oversight has enabled the church and its members to work in more flexible, responsive ways. As a result, the church attracts young intellectuals and researchers who have a deep passion for experimenting on how to make a better society. MÁV school came under the direction of MET when the mayor of the district decided to close the state-run school. Erôs began working as a volunteer and became the director in 2017 and stayed in this position for 2 years. Under his leadership, the goal of the MÁV school was to create a family-like community where equality and freedom for students and staff members. We will discuss what we mean by freedom and how this freedom plays out in our school and among our students later in this chapter, but in short it manifests in two ways. First, students are involved in the decision making of every single detail of school life. Second, the leadership of the school is collective.

The school is located in a district of Budapest characterized by high levels of poverty and inhabitants who identify or are identified as Roma. Thus, the students who attend this school are suffering from a complex array of social disadvantages which include poverty, lack of access to adequate food resources, lack of access to safe play spaces, and entrenched societal discrimination. When Erôs first began working at MÁV it in many ways resembled the kind of school one would expect in such a neighborhood. It functioned according to "prison rules." Students were not allowed to move freely throughout the school grounds and, due to a locked gate, were not permitted to enter and leave the school at will. Police presence was a constant. Through a coordinated effort to (1) identify the specific challenges inherent in working with this unique population, (2) devise clever and implementable strategies to overcome these challenges, (3) build a team that is dedicated to flexibility and creative thinking when it comes to reaching a goal, and (4) work to engender 
trust among the student body, the school under Erôs's leadership was re-envisioned as a welcoming neighborhood intuition. Bathrooms, laundry facilities, and a doctor were available on the premises. Most employees demonstrated a positive and familial attitude towards the children. The children had autonomy and felt that the school is theirs, not simply a place that they go. All of these factors made the school a safe place and a positive environment where both students and staff went gladly. Erôs left the school in 2019 and began a nonprofit educational organization. We cannot speak to the current conditions at the school.

\section{Roma Education}

Most of the students at MÁV school are Roma. This is significant because of the long history of segregated education in Hungary in which children who are identified as Roma are sent to schools for the "mentally disabled" on the basis of their name alone, placed in "catch up" classes where they never effectively catch up, or are positioned at the back of the classroom where their needs and contributions are ignored (Farkas 2004, 2007). Because of a long history of segregated education, there are some unique challenges to providing quality education to Roma students. Here "quality education" refers to lessons that are relevant for the students and create discernable, measurable results.

As scholars of philosophy and anthropology, our work with Roma students has required us to directly confront the dualistic nature of humans-always present, but more readily apparent and visible among those who, owing to their marginalization and discrimination, have not been socialized into the norms of education as standard practice rooted in uniformity and non-contradiction. The concept of dualism highlights the way aspects of reality can be separated into two categories. The philosophy of mind-dualism, for example, provides the framework within which the Western biomedical system functions (Gendle 2016). That is, the mind and the body are treated as functionally separate and independent entities. Implicit in our understanding is the recognition that categorical realities are often contradictory. It is in the sense that it is possible to both love and hate someone with equal ferocity. It is only possible to create the remembrance of a hero is certain elements of their life are strategically erased. Sometimes posited as paradoxes, philosophers have long taught us that life is dualistic and contradictory. Education itself provides an example of the dualism of which we explore in this chapter. It provides a paradox in that the same institution can be both the source of disempowerment and freedom. If we teach to transgress, as bell hooks calls upon educators to do, learning can be a place "where paradise can be created." She continues, "The Classroom, with all of its limitations, remains a location of possibility. In that field of possibility, we have the opportunity to labor for freedom, to demand of ourselves and our comrades, an openness of mind and heart that allows us to face reality even as we collectively imagine ways to move beyond boundaries, to transgress. This is education as the practice of freedom" (Hooks 1994, p. 207). 
Education has long been touted as one of the best methods to alleviate poverty and disadvantage based on the presumption that education leads to greater understanding, respect, and empowerment, and can provide individuals with the tools necessary to improve their livelihoods. According to this ideology, people once armed with an education have an enhanced ability for social betterment, increased access to employment opportunities, and are empowered with knowledge that can protect their community by preventing future discrimination and exploitation. It seems obvious that education should empower due to the knowledge that the lack of access to adequate schooling has severe negative effects. Those without education are more likely to experience "early parenthood, homelessness, poor health, involvement with the youth and adult justice systems, poverty, and unemployment" (Westcott 2005, p. 273). They are more likely to work dead-end, low paying jobs with little chance for advancement or work in the black market or illegal economy.

It stands to reason, then, that if a lack of education is the problem, then the addition of education would be the solution, but the results of the additive model of education have been less than promising research. There is a strong link between low socio-economic status, minority identity, and lack of academic achievement. Historically, this fact has been used as evidence for genetic or racial inferiority (Bond 1981). Such an ideology, for example, underlies the long-held practice of sending Roma children to school for the "mentally handicapped" (ERRC 2004). Although this practice is now largely discouraged, the idea that Roma are somehow naturally mentally disabled or unteachable is a pervasive one in society. Such thinking prevents investment in quality education and exacerbates the segregated systems.

The problem is not with the students themselves, but with an unequal system that treats them as inferior. Schools for low-income, minority students are often lacking in resources and have overflowing classrooms and inadequately trained teachers. As a result, students in these schools have little opportunity to advance their education. The inequity in the education system serves to maintain class divisions. Students are taught their prescribed roles and kept in their prescribed social place in the classroom. Teachers are unconsciously transmitting class and cultural rules to their students, and therefore, the classroom environment reifies the social hierarchy. It does not break it down. It is for this reason that education has often been used as a tool of colonial power. Residential schools for Native Americans, for example, were advocated as a means to "save" and assimilate indigenous groups, produce cultural conformity, and ensure "a homogenous body of 'educated' men and women who would be well-suited for their particular roles" (Kelm 1998, p. 58).

Given this, education following the standard model will not lead to societal change. Paulo Freire (1968) labels this the "banking model" of education in which "knowledge is a gift bestowed by those who consider themselves knowledgeable upon those who they consider to know nothing" (p. 58). He proposes a "pedagogy of the oppressed," which "must be forged with, not for, the oppressed in the incessant struggle to regain their humanity" (p. 33). The teacher does not simply teach but engages in a dialogue with the students. In a Frieren pedagogy, learning happens through the posing of problems which teacher and student challenge through discourse and debate. As such, rather than replicating the oppressed/oppressor 
dichotomy, education is a subversive force, which provide the oppressed with an awareness to initiate societal transformation. In this chapter, we provide the theoretical basis for understanding the paradoxes implicit in the effort to education drawing upon our work with disadvantaged students, most of whom identify as Roma. We explore iterations of this dualism that present challenges to the aim of providing equitable education to the most disadvantaged youth who have been largely excluded from the education system.

\section{Dualism and the Challenges to Equitable Education}

\section{The Paradox of Hedonism}

If Aristotle's postulate is true that "ALL men by nature desire to learn," then the job of the educator would be easy. The pupil desires to learn and is open to the knowledge that the educator imparts. Learning, then, brings pleasure, and, as early hedonists assert, all people seek out pleasure and avoid pain (Annas 1993; Feldman 2004; Lampe 2015). Any teacher, however, knows this description does not match what actually happens in the classroom, particularly educators of marginalized students. For many Roma youth, because of their experiences of discrimination and segregation, education brings with it the promise of pain. For very apparent reasons, they have come to hate the education system, the rigid structure of schooling, and the process of learning. This hatred does not come from nothing. Students identified as Roma are forced to sit in the back of her class where, if not being ignored by classmates and teachers, are ridiculed. Worse still many who are identified as Roma are erroneously sent to a school for the mentally handicapped when young, deprived of any opportunity to learn in a nurturing environment. Almost every Roma student has similar stories. It is no wonder, then, that education is pain and they do not desire to learn when they come to schools like MÁV school.

If the students feel that education is pain, then we must accept that they feel pain. Their truth is not an intellectual or linguistic product, but it is based on raw experience. It is the same way that one will recoil in pain if they touch fire. Given this, we cannot work from the assumption that "by nature they desire to learn." That is, we cannot follow the standard models of education and expect that the students will meet us. In an experimental classroom, the student will feel pain due to the extreme difficulty of the theoretical tasks they are given, so in many cases they capitulate, which leads to conduct often interpreted as "behavioral problems." Thus, begins a vicious cycle. The way to counter the vicious cycle is to engage students as active learners such that they can relate their own experiences to their learning. When they do this, it will become obvious that using knowledge can bring pleasure.

The paradox of hedonism is that the desire of pleasure can make pleasure impossible. Simply put, having knowledge increases one's ability to experience pleasure but if the process of gaining knowledge is unpleasurable, it will be avoided. As such, learners need a rational calculation of interests to be able to assess the 
manner in which deeper and lasting pleasure can come out of pain. Experimental pedagogy is focused exactly on this. For a successful educational philosophy, it is necessary to accept, not dissolve the paradox of hedonism.

There are two methods that can assist the educator in accepting the paradox. The first is to make learning as pleasurable as possible by focusing on the practical applications of knowledge. Math lessons, for example, should focus on money skills. Language arts should come from reading newspaper articles dealing with events of direct importance and interest to the student. Another possible solution is to attempt to reduce the distance between the pain and the pleasure of knowledge. A simple gifting system can provide a dopamine release that enables the student to have a pathway through the pain to pleasure. The reward does not have to be large. Both authors have experimented with this method by enacting a point system. Points are relatively easy to earn and can be cashed out for rewards that are desirable. Such a system increases class attendance and engagement, and, of course, provides the direct pleasure of learning rather than the abstract pleasure of which most philosophers concern themselves. Thus, their experience changes and they can be opened up to the world full of exciting things to learn.

\section{Monadic Structure of Empirical Data}

According to Erving Goffman (1959) dramaturgical theory of performance, societal interactions occur on a stage in which actors meet each other in the frontstage region and are uninformed about the preparations that occur in the backstage region. Essentially, whenever we encounter another individual, we are basing our impression of that person based on the character they embody in the frontstage region. In these interactions, people are in control of some of these aspects-this is what they "give." However, the aspects of self that people "give off" are unconscious and indirect. An individual can be stigmatized or "discredited" for the impressions that they give off (Goffman 1963).

Goffman's theory provides a useful framework for understanding how individual encounters cannot be understand out their societal context. In the case of the Roma, much is already "known" about them. In public discourse, they are commonly known to be criminal, dirty, and, in the case of our children, unteachable. The Roma, according to Edward Said (as cited in Nicolae 2006), are the only people about whom anything can be said without challenge or demurral. Thus, Roma, due to what they "give off" through their skin color and mannerisms, are discredited. As educators of Roma, we are trained not to base our assumptions on stereotypes, but we are not immune to being affected by what our students "give," or in other words, their managed identities. Working with Roma youth, we constantly get impressions from them. We receive data and use this data to form a working understanding of who that individual is. The hidden conceit of our intelligence is that the data we receive forms a coherent schema of the person. 
In our work with Roma and disadvantaged youth, we are constantly receiving impressions about who they are and of what they are capable, which can, if we are not careful, lead to a monadic structure of empirical data. That is, we collect observable data in our interactions with them, and we run the risk of using that data to form a unified, static image of the person. However, the constant flow of the pieces of pictures and senses will not necessarily show us a unified picture. The data we receive is not immutable, but fluctuates, develops, and changes. A personality is constantly changing. In our interaction with Roma youth, we are largely basing our estimations on what the individual "gives." Here the theoretical framework of frontstage and backstage helps. Presumably, one is relatively in control of what they give. It is erroneous, however, to assume that this managed identity represents one's true self. Rather, this is still a performance that takes place in the frontstage region, and this performance can change over time. If educators base their estimation of a person based on a static notion of who they appear to be, they are working from a flawed model.

In order to address this challenge, educators should recognize that they form presumptions about students. Recognizing this, it is essential to fight against the natural tendency of rigidity and instead be open to the possibility of change. We must always assume the possibility of change while taking seriously the data input coming from students on a daily basis. We must assume that each child is unfinished and their personality if unfinished. This premise focused on possibilities, not on the challenges. When we expect our children to fail, they will fail, but when we open ourselves to the possibility that they can change, they are able to change and succeed. The goal, then, is acceptance, or as one educator in Hungary explained, acceptance toward the personality, not the deeds (personal communication, March 2020).

\section{The Paradox of Freedom}

Educational institutions for Roma must teach to transgress (Hooks 1994). Freedom should be the primary goal. It may seem that the children, especially those in the lower grades, are not ready to be able to take on the responsibility of engaged dialogue. However, it is possible for education for freedom to be put into practice by taking the students' decisions seriously and supporting them in their endeavors. The practice of freedom is not without its challenges and presents yet another paradox. On the one hand, real pedagogical advancement is only possible is we regard freedom as the primary goal in order to assist in the creation of democratically minded citizens. On the other hand, freedom brings with it great responsibility. Freedom is a burden that often even the most educated are often unable to carry.

For many young students, particularly those who have not be socialized into the rigid structure of schooling, freedom is defined as the unlimited access to pleasure. How is it possible to work with someone whose actions resulting from this definition of freedom are unacceptable? Freedom defined as the access to unlimited pleasure is counterproductive to a healthy society. Rather freedom is the ability to promote 
capacities to the greatest extent possible in order to breed fulfillment of human life in the direction of progress.

It must be noted that the extreme desire for freedom is one often associated with a life on the margins. In their book Lilies of the Field: Marginal People Who Live for the Moment, Day et al. (1998) bring together ethnographic works of peoples, who due to their marginalized position in society, often defined by poverty, eschew "mainstream notions of work, productivity, and long-term economic planning" choosing instead "to take a 'natural' abundance for granted and to forage their own subsistence" (p. 1). For the Roma, this presents itself in the manner in which Roma "harvest" from the non-Roma while existing in a kind of "brotherhood" amongst themselves. To non-Roma, this living for the moment appears at best to be laziness and at worst criminal. Oscar Lewis (1966) labeled this behavior as a "culture of poverty." Emerging from an ethnography of impoverished Puerto Rican families living in New York, Lewis posited this theory in order to explain why poverty persisted from generation to generation. Immediately and rightly critiqued, the "culture of poverty" framework assumes capitalism as the norm. That is, it assumes that all peoples should endeavor to be productive and contribute to the capitalist economy. The strength in the metaphor of the Lilies of the Field is that is does not assume that marginalized people should endeavor towards productivity and, instead, find contentment in a life defined by its immediacy. In this, freedom itself makes it impossible to reach a higher level of freedom, the level afforded to those recognized as full members of a society.

In practice, the act of living in the moment is defined by behaviors deemed abhorrent by the general public. Roma are thought to be lazy, unmotivated, and, in many cases, criminal. Educators, then, are tasked with the burden of sharing with Roma youth the pleasure of education when pleasure for them has been defined by a kind of freedom that until now has removed them from the responsibilities of and trappings of societal expectations. Educators should not force upon the students one vision of the future deemed worthy of saving; rather, they should take into consideration that there is more to the fulfillment of human life. Education offers freedom, but it is freedom with responsibility. Pain of learning can turn into pleasure; the unbearable freedom of life can be pleasure of life. This can only happen, however, if lessons are directly applicable. The institution of schooling is often focused on abstract lessons. Such abstraction does not work with a student for whom learning is painful and freedom is within one's grasp.

In order to address the paradox of freedom, we suggest three pragmatic solutions. This first is to remove the visible reminders of servitude. In MÁV school, police presence and the optics of prison life were removed. In addition, murals and colorful artwork were exposed to make the school a comforting place to be. A second solution is to offer non-abstract lessons. Students should be able to understand the direct relevance of lessons. Finally, a third solution is to involve students in decision making. Although the final decision lies with the headmaster, students' input is gathered, valued, and taken into consideration. 


\section{The Paradox of the "Morality of Helping"}

The final challenge that we will explore in this chapter relates to the educators and staff rather than to the Roma students. The biggest paradox in any helping profession lies in the demand for reciprocity. Those who help, such as people who make the conscious decision to enter the field of social work or work at a school for disadvantaged youth, are often seeking greater emotional fulfillment than they would find in other professions. They expect that their workplace will give more than it will take away. This is a reasonable expectation as it is selling point of these professionshelp others, help yourself. We must, however, ask the question: what if this is not true? What if the work is not gratifying? There are many reasons why this could be the case - those whom we seek to help may lie to us, attack us, and cause unanticipated and seemingly insurmountable problems. What if those we help, rather than expressing gratitude, express ambivalence, or even anger? These are the most troubling questions of our work and it draws into question the motivation of our work. That is, are the helpers really seeking to help the needy or just themselves? The tragedy of our work is that oftentimes the latter is the answer to the question as we see many people leaving the work and the profession due to lack of fulfillment. Thus, if we cannot address this paradox with merciless honesty, we will be unable to move forward in this work.

In thinking of solutions for how to deal with this paradox, we suggest approaching the act of helping in the similar vein as responding to a potential emergency situation. Pilots, emergency room physician, first responders-all of these professionals are constantly preparing for emergencies. It is for this reason that many of us survive our interactions with them. Of course, someone in the helping profession should be glad when their love is reciprocated, but helpers should consider their work as being constantly in emergency mode. That ensures that professionals in these positions are able to continue their work even when the unexpected happens. Another way of thinking about this is to use the model provided by the philosopher Schopenhauer. Schopenhauer was a contemporary of Hegel who was lauded as the greatest philosopher of his time, but Schopenhauer hated Hegel. In defiance, he announced his lectures at exactly the same time; therefore, no one showed up. Regardless, he kept presenting his lectures to an empty room. We can learn from this apparent exercise in futility. Do not cease to function, even when receiving nothing in return.

Another paradox related to the morality of helping relates to the character of the helpers who must be flexible, caring, and responsive, while at the same time maintaining rigidity in the face of defiance and be unfazed when directly challenged. They must be able to deflect potential violence in a calm manner. This is the only effective attitude when it comes to working with children living in extreme poverty. Character development, then, is an extremely important part of this work. It is intangible, but a basic condition of success. So, what is this character? It is the thirst for an ability to fight for knowledge. It is the ability to profess, redefine, or create one's own identity paired with self-confidence and conviction that one can make the 
world a better place. It is the ability to work for the best and most positive outcome even if it means staring into the face of an angry mob.

Finally, the most important aspect of helping is often the most overlooked because it is considered unempirical (Domínguez 2000). That is, it is only possible to perform fruitful work in an affectionate environment. Love is not passivity, but, rather, a positive acceptance of reality. Love is what provides helpers with the ability to move through mistakes. It is what tells students that we are truly there for them.

\section{In Practice}

Most of the students at MÁV are ethnically Roma, but the few of them are not. The common denominator of the two groups is that both are underprivileged in Hungarian society Throughout this chapter, we have highlighted many of the challenges unique to educating marginalized students due to the intrinsic dualistic nature of humans, evident in educational institutions. We have also proposed potential solutions to addressing each challenge. The team at MÁV school applied an experimental approach and, thus, the suggestions have been put into action. In this final section, we outline some of the strategies that have worked for in this school. It is important to note, that the work is never considered done. That is, the most important aspect of the program is to continue innovating and remain flexible and open to new possibilities. Thus, the teachers and administration are constantly researching best practices and evaluating the current learning outcomes.

During the time that Erôs served as headmaster, four basic subjects were taught at MÁV: Laws and Nature, Space and Time, Money Science, and Sports. As discussed previously, teachers sought to make the knowledge imparted in these classes as applicable and as hands on as possible. That is, students learned math by counting money and history by building models of ancient weapons. In addition to these subjects, students were also exposed to music therapy through an Austrian partner and English classes taught by native speakers. Education was not bound to the classroom. Instead, every Fridays were built around integrated learning. Students built knowledge on one theme by rotating through several stations with teammates. In addition, students are more frequently learning in a one-to-one mentoring situation rather than in a full classroom. This intensive model of education is made possible through a dedicated staff, including social workers, a large pool of volunteers, and a small student body.

The hands-on lessons meant that knowledge was accessible and addressed all of the dualistic challenges posed above. The interactive nature made it pleasurable for both students and teachers. As such, learning was pleasurable, and educators received immediate reward for their work. Learning, then, became an activity in which students and teachers could participate in and enjoy together, thus laying the groundwork for an environment that unleashes the emancipatory potential of education. 
When MÁV school began, the children were fairly resistant to learning. The experiment at MÁV began with the knowledge that they would not learn until they started to desire knowledge. We recognize that the successes that have been seen at the school are not necessarily available to most education institutions, but we reject the notion that Roma students, due to their marginalization, are unreachable. Both authors have worked in and made connections with educators in numerous educational institutions that teach disadvantaged youth. Without fail, we have seen that in order to be successful, the school administrators, staff, and teachers must create new models. In many cases, these models do not look like education as usual. Nor do they follow to state-sponsored curriculum.

We can propose, based on our experiences and our observations, five strategies that educators can implement to provide a successful educational framework. First, it is necessary to break discipline reciprocity. In Hungary, as in much of Central and Eastern Europe, educational disciplinary models tend to be punitive. When working in this model, it is logical for educators to perceive negative behavior and respond negatively. Educators with whom we spoke claimed that such disciplinary measures do not work with their students. Rather, the students can be reached through reward and positive reinforcement. Second, it is important to view the institution as a unified entity. Teachers and students should work together to understand the whole school as a referent group without sides, castes, or factions. As such, when the institution benefits, its members benefit. Third, educators should work on repairing the students' perception of the "school as enemy." In a successful model, students should understand the school project not, as they often do, an alien invasion counter to their identity, but as a holistic approach designed to work with them to build a better future. The fourth implementable strategy is to concentrate on the process of learning instead of focusing on trying to produce documentable knowledge. In practice, this means that teachers must focus their energies on teaching the language of school and the movement of learning rather than recitation of study materials. Using this framework, anything can be subject matter since the goal is learning to learn and encouraging students to be open to the learning process. Finally, the above four strategies are possible if schooling is imparted through interchangeable and open subject matters. This enables a student to drop in and out of the schooling environment with greater ease because they can predict the directions of study. It also enables to educator to teach through hidden curriculum, such as providing math education in the guise of talking about money matters.

The manner in which our proposals may be implemented will differ based on the needs of the student body and goals of the educator. However, what all successful educators share in common is a desire to accept the students as they are, nurture of love of education in whatever form that takes, and foster the students' real skills, even as they may differ dramatically from the expected norm. We argue that it is necessary to develop a style of teaching and learning that meets the students where they are, and this is a model that is open to all educators. 


\section{References}

Annas, J. (1993). The morality of happiness. Oxford: Oxford University Press.

Anyon, J. (1980). Social class and the hidden curriculum of work. Journal of Education, 162(1), 67-93.

Bond, G. C. (1981). Social economic status and educational achievement: A review article. Anthropology and Education Quarterly, 12(4), 227-257.

Bourdieu, P. (1977). The economics of linguistic exchange. Social Science Information, 16(6), 645-668.

Danova, S. (2004). Patterns of segregation of Roma in education in Central and Eastern Europe. In E. Rekosh \& M. Sleeper (Eds.), Separate and unequal: Combating discrimination against Roma in education, a source book (pp. 3-14). Budapest: Public Interest Law Initiative.

Day, S., Papataxiarchis, E., \& Stewart, M. (Eds.). (1998). Lilies of the field: Marginal people who live for the moment. Boulder, CO: Westview.

Derdák, T., \& Varga, A. (1996). Az iskola nyelvezete-idegen nyelv ("Schoolish" as a foreign language). Regio: Kisebbségi Szemle (Minorities Review), 7(2), 150-175.

Domínguez, V. (2000). For a politics of love and rescue. Cultural Anthropology, 15(3), 361-393.

European Commission. (2004). The situation of Roma in an enlarged European Union. Luxembourg: Office for the Official Publications of the European Communities.

European Roma Rights Center. (2004). Stigmata: Segregated schooling of Roma in Central and Eastern Europe. Budapest: ERRC.

European Union Monitoring and Advocacy Program. (2007). Equal access to quality education for Roma (Vol. 1). Budapest: Open Society Institute.

Farkas, L. (2004). Education, education, and more education. http://eumap.org . Accessed 27 Sept 2006.

Farkas, L. (2007). Segregation of Roma children in education: Addressing structural discrimination through the race equality directive. Brussels: European Commission.

Feldman, F. (2004). Pleasure and the good life. Oxford: Oxford University Press.

Foucault, M. (1977). Discipline and punish: The birth of the prison. New York: Vintage Books.

Freire, P. (1968). Pedagogy of the oppressed. New York: Seabury Press.

Gendle, M. H. (2016). The problem of dualism in modern western medicine. Mens Sana Monographs, 14(1), 141-151. https://dx.doi.org/10.4103\%2F0973-1229.193074.

Goffman, E. (1959). The presentation of self in everyday life. New York: Anchor Books.

Goffman, E. (1963). Stigma: Notes on the management of a spoiled identity. Englewood Cliffs, NJ: Prentice Hall.

Hooks, B. (1994). Teaching to transgress. New York: Routledge.

Kelm, M. (1998). Colonizing bodies: Aboriginal health and healing in British Columbia, 1900-50. Vancouver: UBC Press.

Kingsley, P. (2019). He used to call Viktor Orban an ally. Now he calls him a symbol of fascism. The New York Times. Retrieved from https://www.nytimes.com/2019/03/15/world/europe/ vi k tor - o r b a n - h ungary - i vanyi. ht m l ? f b c lid =I w A R 3 V O jezqWUjkGOiPTCpvgmgssBQPCu3KerNTWgbJZMoYFW60YJfQAkyDw

Lampe, K. (2015). The birth of Hedonism. Princeton: Princeton University Press.

Lewis, O. (1966). La vida: A Puerto Rican family in the culture of poverty-San Juan and New York. New York: Random House.

Mizsur, A. (2018). Ebben az iskolában csak gerillák tanítanak (In this school only guerillas teaching). Index. Retrieved from https://index.hu/belfold/2018/02/20/abcug_oktatas_ szegregacio_eros_mate_wesley_janos_altalanos_iskola/

Nicolae, V. (2006). Words that kill. Index on Censorship, 35(1), 137-141.

O'Nions, H. (2010). Divide and teach: Educational inequality and the Roma. The International Journal of Human Rights, 14(3), 464-489. https://doi.org/10.1080/13642980802704304. 
Rorke, B. (2016). Segregation in Hungary: The long road to infringement. European Roma Rights Centre Blog. Retrieved from http://www.errc.org/blog/segregation-in-hungary-the-long-roadto-infringement/106.

Timmer, A. D. (2017). Educating the Hungarian Roma: Nongovernmental organizations and minority rights. Lanham, MD: Lexington Books.

Westcott, E. (2005). Equality of opportunity and inclusion. Journal of Education and Teaching, 31 (4), 273-274.

Willis, P. (1977). Learning to labor: How working class kids get working class jobs. New York: Columbia University Press.

Open Access This chapter is licensed under the terms of the Creative Commons Attribution 4.0 International License (http://creativecommons.org/licenses/by/4.0/), which permits use, sharing, adaptation, distribution and reproduction in any medium or format, as long as you give appropriate credit to the original author(s) and the source, provide a link to the Creative Commons licence and indicate if changes were made.

The images or other third party material in this chapter are included in the chapter's Creative Commons licence, unless indicated otherwise in a credit line to the material. If material is not included in the chapter's Creative Commons licence and your intended use is not permitted by statutory regulation or exceeds the permitted use, you will need to obtain permission directly from the copyright holder. 